\title{
THE GAMETOPHYTES OF OPHIOGLOSSUM PALMATUM L. ${ }^{1}$
}

\author{
Michael R. Mesler \\ Department of Botany, University of Michigan, Ann Arbor 48104
}

A B S T R A C T

Gametophytes of the epiphytic species Ophioglossum palmatum L. are described for the first time, bringing the number of Ophioglossum species with known gametophytes to 11 . Although somewhat unusual in terms of (a) degree of branching, (b) the marked expansion of the basically cylindrical axis in some cases, and (c) production of stout, papilla-like rhizoids, the gametophytes of $O$. palmatum are more similar to other Ophioglossum gametophytes than they are to the gametophytes of Botrychium or Helminthostachys. Gametophyte characters do not provide strong evidence for placing $O$. palmatum into a separate genus, viz., Cheiroglossa. The gametophytes of $O$. palmatum most closely resemble those of the other epiphytic species in the genus, $O$. pendulum. This similarity suggests a need for a reevaluation of modern taxonomies which, in general, treat the two species as only distantly related.

ThE GEnUS Ophioglossum sensu lato comprises some 30 species of primarily small, terrestrial, fern-like plants. Only two species occur regularly as epiphytes. One of these, $O$. pendulum L., which extends in the Old World tropics from Madagascar east to the Hawaiian Islands, is characterized by the production of long, pendant, ribbon-like leaves which are simple or forked as many as three times. Each leaf bears a single fertile spike. In contrast, the other epiphytic species, $O$. palmatum L., typically bears several fertile spikes per leaf. The leaves of this species have an expanded basal blade region which divides distally into a variable number of lobes. While best represented in the New World tropics and southern peninsular Florida, $O$. palmatum has also been reported from Madagascar, Zaire, Reunion, the Seychelles, and South Vietnam.

Divergent concepts of the relationships of the epiphytic species to one another and to the other members of the genus are reflected in differing taxonomic treatments at the generic and subgeneric levels. Whereas some authors have assigned $O$. palmatum and $O$. pendulum to separate genera, Cheiroglossa Presl and Ophioderma (Blume) Endlicher, respectively, others have placed them in separate subgenera, adopting a broader concept of the genus Ophioglossum. At least one author (Nakai, 1925, 1926) regarded them as more closely related to each other than to the terrestrial members of the genus and accorded them common generic status under the name Ophioderma (Blume) Endlicher.

\footnotetext{
${ }^{1}$ Received for publication 24 September 1974.

I would like to express my sincere thanks to the following individuals for their generous assistance: $W . H$. Wagner, Jr., C. E. Delchamps, J. G. Bruce, D. Beale, R. E. Hair, and J. R. Jennings. I am especially grateful to Professor Wagner for suggesting this research project and for critically reading the manuscript.
}

All previous interpretations of the relationships of the members of the genus Ophioglossum s. $l$. have been based entirely on the sporophyte. Gametophytes are known from only 11 species and in many cases incompletely (see Boullard, 1963, for a review of previous reports; also Mahabale, 1937a, b, c; Mesler, 1972, 1973). Although Campbell (1907, 1911) and Lang (1902) described the gametophytes of $O$. pendulum, those of $O$. palmatum remained unknown until recently (Mesler, 1972). The objectives of the present study are as follows: (1) to provide a detailed account of the structure and development of the previously undescribed gametophytes of $O$. palmatum; (2) to present preliminary observations on the embryos of this species; (3) to describe the natural history of the gametophytes as they occur in southern Florida; and (4) to consider the problems of the evolutionary relationships of $O$. pendulum and $O$. palmatum and the taxonomic validity of the genus Cheiroglossa in light of the new evidence from the gametophyte generation.

Materials AND METHODS-Collections of gametophytes from a single locality in Collier Co., Florida, were made in December, 1971, and March, 1972. Although once relatively abundant in southern Florida, $O$. palmatum is now possibly in danger of extinction there (Mesler, 1974). Previous sanctuaries for the species have burned following extensive drainage programs in the area. In addition, the superficial resemblance of $O$. palmatum to Platycerium (hence the colloquial name "dwarf staghorn fern"), coupled with the distinctive appearance of the species in its own right, has led to vandalism for horticultural purposes. The species, however, has not been successful in cultivation.

The population of $O$. palmatum visited by the 


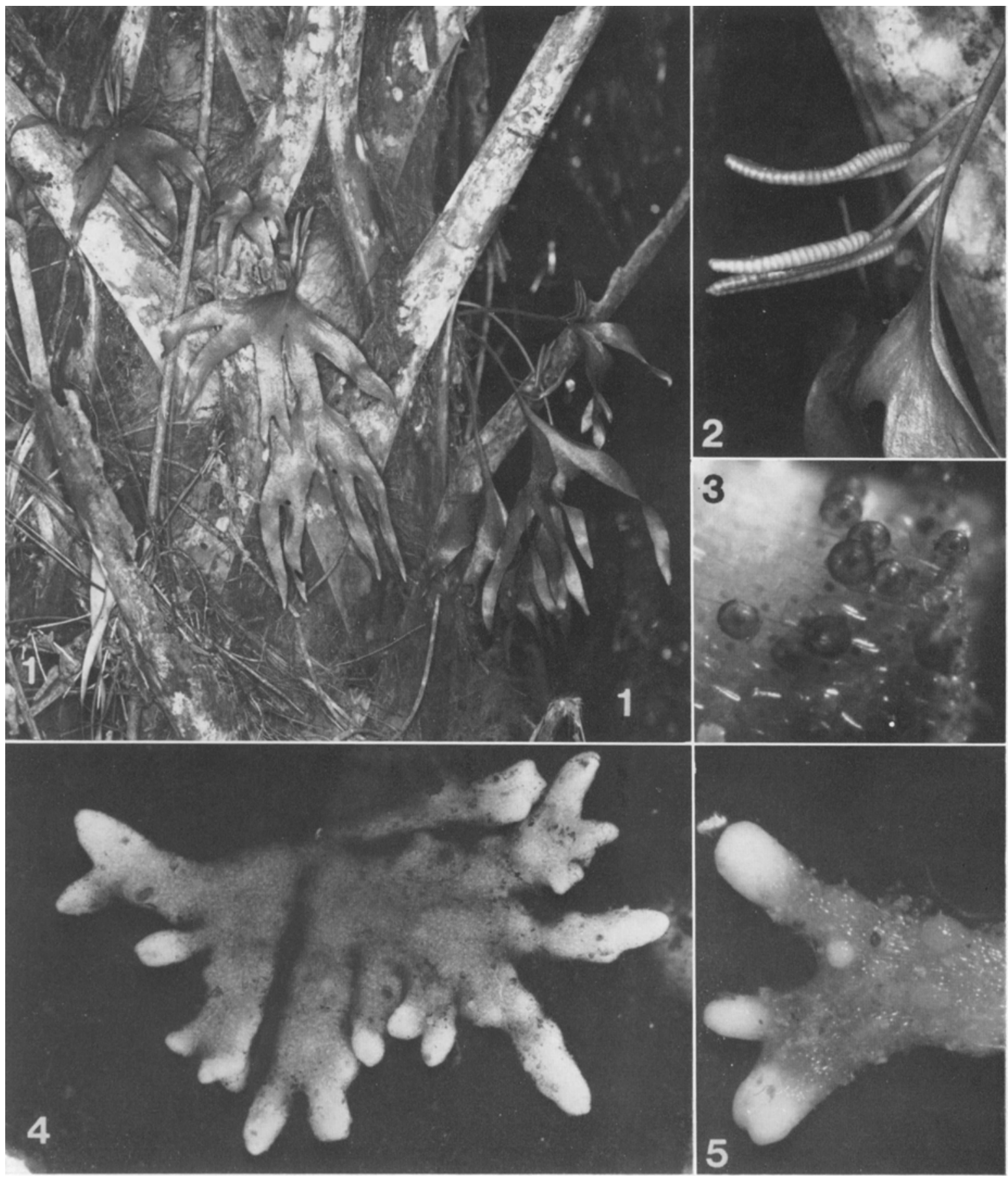

Fig. 1-5. Ophioglossum palmatum. 1. Sporophytes growing on the cabbage palmetto. $\times 0.18$. 2. Fertile spikes at top of the stipe. $\times 0.75$. 3. Rhizoids, surface view (stained). $\times 80.4$. Entire gametophyte, showing branching confined to essentially a single plane. $\times 14$. 5. Unequal apical division (living, unstained specimen). $\times 20$.

author is confined to a mixed hardwood association, occurring along a river in the dwarf cypress glades of southern Florida. Although signs of past fire damage are evident, extensive burning of the area has not occurred in recent years. The dominant tree species present are Acer rubrum, Quercus virginiana, Taxodium distichum, and Sabal palmetto. The gametophytes of $O$. palmatum 
were found growing in the decaying matter that accumulates between the imbricate leaf bases of the Cabbage Palmetto. After removing portions of the tightly held leaf-base armor, individual gametophytes as well as quantities of the substratum in which they were growing were collected. The substratum yielded additional gametophytes after closer examination in the laboratory.

Gametophytes were fixed in FPA or medium chrome-acetic, the latter solution yielding better histological preparations. Photographs of whole specimens (some of which were surface stained with iron hematoxylin, following a procedure developed by $\mathrm{D}$. W. Bierhorst) were taken through an ordinary dissecting microscope fitted with a paper diaphragm for improved depth of field or with a Leitz Aristophot $4 \times 5$ view camera with a 32-mm lens. Some of the gametophytes were subsequently dehydrated in a t-butanol series, embedded in Paraplast, and sectioned at 10-12 microns by standard methods. Sections were stained with either safranin and fast green or Sharman's (1943) tannic acid-iron alum-orange G-safranin. Other gametophytes were cleared in a mild clearing reagent developed by Herr (1971). The cleared gametophytes were examined and photographed with a Zeiss compound microscope equipped with Nomarski interference-contrast optics. By focusing at various planes, it was possible to obtain a series of relatively undistorted optical sections through portions of intact specimens. This method was of little use, however, in regions of high cytoplasmic density such as gametophyte apices.

OBSERVATIONS-Of the tree species present at the Collier County locality, only one, Sabal palmetto, is colonized by Ophioglossum palmatum. Attaining heights of 5 meters or more at this site, the Cabbage Palmetto is characterized by a woody mantle of persistent, imbricate leaf bases which on most plants extends from the crown down to near ground level (Fig. 1). The decaying materials which accumulate within and underneath the leaf-base mantle, providing the substratum for the gametophytes and sporophytes of $O$. palmatum, appear to be derived primarily from the decay of leaf-base tissues. Fall litter is unlikely to contribute significantly to the buildup of organic debris because of the tightly appressed nature of the palmetto leaf bases. Small roots of Rhus radicans, however, are frequently encoun- tered beneath the leaf bases and, upon decomposition, they too may add to the organic substratum. The texture and moisture content of this substratum varies from relatively moist and compact to dry, loose, and fibrous.

A survey of the population indicated that the sporophytes of $O$. palmatum are not confined to specific zones on the palmettos; instead, plants of differing ages were observed at various heights along the stems, from $0.5 \mathrm{~m}-5 \mathrm{~m}$. The roots and stems of $O$. palmatum are completely covered by the palmetto leaf-base mantle; only the somewhat fleshy, lobed leaves extend beyond it (Fig. $1,2)$. The leaves exhibit considerable variation in terms of size, number and shape of lobes, presence or absence of fertile spikes, and number of fertile spikes borne by fertile leaves. When mature, all leaves are pendant or arching, their laminar segments oriented approximately parallel to the surface of the palmetto.

Gametophytes of $O$. palmatum were found in large numbers at the locality. Although perhaps only a dozen palmettos bearing sporophytes were investigated for gametophytes, nearly two hundred complete gametophytes and several hundred detached gametophyte apices were collected. These were not, however, randomly distributed among the palmettos. The amount of moisture present at the interface of the palmetto leaf-base mantle and the stem strongly influences gametophyte distribution. Those palmettos with an essentially dry mantle and having an accumulation of dusty, loose debris, invariably lacked gametophytes. The best gametophyte growth was observed on palms with tightly appressed frond bases which offered a relatively more moist and compact substratum.

Gametophytes - The nongreen, mycotrophic gametophytes of $O$. palmatum are fundamentally cylindrical and much branched. However, they exhibit a considerable degree of variation in terms of overall form, cross-sectional shape, and size (Fig. 4, 6-23, 26, 28). Branches are most often oriented in several planes but may be confined to a single plane. In the latter case, the development of stellate or nearly stellate forms can occur (Fig. 4). For descriptive purposes, many gametophytes may be regarded as comprising two distinct regions: an expanded and sometimes flattened main body, and a variable number of smaller, cylindrical or subcylindrical branches

Fig. 6-27. Ophioglossum palmatum. 6-20. Variation in gametophyte form (preserved, unstained specimens). $\times 2.8$ (scale in Fig. 20 in $\mathrm{mm}$ ). 21,22 . Entire gametophytes (preserved, unstained). $21, \times 11 ; 22, \times 13.23$. Gametophyte bearing several young embryos (living specimen) $\times 2.5$. 24. Nearly equal apical division. $\times 15$. 25. Four embryos on gametophyte shown in Fig. 23. $\times 12.26$. Entire gametophyte (stained). Arrow indicates branch undergoing latent development at base of gametophyte. $\times 14$. 27. Operculum of antheridium (stained). $\times 30$. 


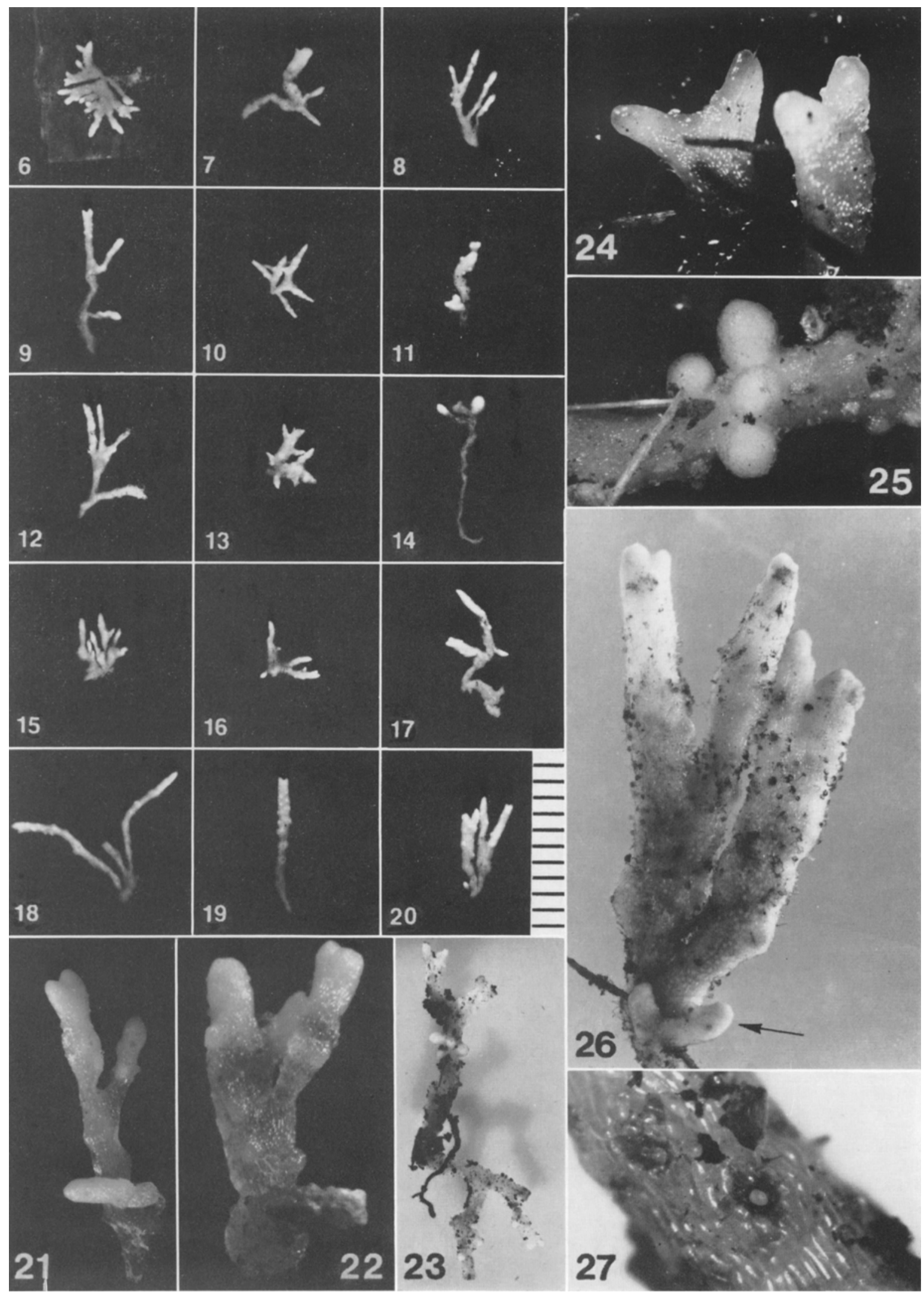


(Fig. 4, 12, 13, 28). In reality, however, there exists a continuum of mature forms, beginning with gametophytes consisting solely of cylindrical or subcylindrical axes and leading to those that show a clear differentiation into main body and subordinate branches. The average diameter of the cylindrical branches is $0.75 \mathrm{~mm}$; however, expanded portions of some gametophytes are as wide as $4 \mathrm{~mm}$. Length is variable, depending on age and type of development. The longest axis measured $22 \mathrm{~mm}$.

Gametophyte color varies from white at the growing points to brown in older regions. The surface of the gametophyte may be entirely smooth or, more commonly, is covered by zones of distinctively stout, 1 - to rarely 2 -celled, papillalike rhizoids (Fig. 3, 26, 28, 33). The rhizoids impart a rough appearance to the gametophyte and can easily be observed under field conditions with $10 \times$ magnification. In addition, some axes have a distinctly warty appearance due to the production of several large, bulging antheridia (Fig. $5,19)$. This character, however, is not constant and depends on the number and size of antheridia present on a particular axis and the relative size of the axis itself. Maturation and dehiscence of antheridia is invariably accompanied by an accumulation of yellow and brown pigments on the outer surface of the antheridium and on adjacent tissues. Necks of archegonia do not project far above the gametophyte surface and are usually not conspicuous externally.

The cells of the gametophytes are uniformly parenchymatous. Starch grains are concentrated near the apex and occur in cell layers surrounding developing gametangia in older parts of the axis but are generally absent in cells occupied by the endophytic fungus. The fungus, on the other hand, is absent from meristematic tissues and is best developed in older cells of the gametophyte. The distribution of the endophyte is otherwise quite variable. Whereas it often occupies only the center of the gametophyte, in many cases it can be observed in only half of the axis or at the periphery. In older parts of the gametophyte, corresponding to the position of post dehiscent gametangia, any zonation evident in young parts completely disappears, and all cells are usually occupied by the fungus.

The endophytic fungus evidently enters or leaves the gametophyte via the rhizoids, as no other points of connection were observed (Fig. 33). Not all rhizoids that were observed, however, contained hyphae. The fungus consists of nonseptate, multinucleate hyphae which appear in a variety of forms similar to those observed by Campbell (1907), Lang (1902), and Burgeff (1938) for O. pendulum and Bruchmann (1904) for O. vulgatum (Fig. 32-35). A single hypha may penetrate several cells without branching or branching only a few times, but in other instances many branches are produced over a short distance. A characteristic feature of the endophyte, observed in all specimens, is the expansion of the hyphae within cells to form irregularly shaped, darkly staining vesicles (Fig. 36, 37, 47, 48). Several of these may be present in a single cell.

Growth of the axis results from the activity of a radially symmetrical apical meristem that is circular to elliptic in cross section. No single apical cell was observed; instead, a small group of wedge-shaped or columnar cells appear to function as initials (Fig. 29). The outermost layer divides (a) periclinally to give rise to derivatives whose subsequent divisions form the main body of the gametophyte and (b) anticlinally to form a relatively distinct superficial layer. The latter is characterized by its relatively small numbers of starch grains and undergoes a limited number of periclinal divisions which produce gametangial initials as well as add new cells toward the center of the axis (Fig. 30, 31). These periclinal divisions are restricted to the apical end of the gametophyte and usually occur at a time when the subjacent cells of the axis are still meristematic.

The development of expanded portions of the basically cylindrical body occurs at the apex and immediately behind it and does not depend on the activity of a secondary thickening meristem functioning in older regions of the gametophyte. This conclusion is based on (a) the restriction of division figures to the apical ends of the gametophytes and (b) the absence of a well-defined mantle of radially aligned cells in older parts of the axis as is produced by the peripheral thickening meristem of Botrychium gametophytes (Bierhorst, 1958). Increase in the diameter of the gametophyte and deviation from the circular

Fig. 28-42. Ophioglossum palmatum. 28. Entire gametophyte. Arrow indicates branch undergoing latent development at base of gametophyte. $\times$ 14. 29. Longitudinal (nonmedian) section through gametophyte apex. $\times 560$. 30. Cross section through apical meristem of gametophyte, showing relatively distinct superficial cell layer. $\times 500$. 31. Same, but section further from apex. $\times 270$.-Fig. 32-37. Fungal endophyte. 32, 34, 35. Hyphae in body of gametophyte. $32, \times 625 ; 34, \times 560 ; 35, \times 825$. 33. Hypha in rhizoid. $\times 575.36,37$. Fungal vesicles in gametophyte cells. $36, \times 500 ; 37, \times 450$.-Fig. 38-40. Longitudinal sections through archegonia. 38, $\times 270 ; 39$, $\times 225 ; 40, \times 225$. 41. Surface view of archegonium, showing dehiscence via folding apart of upper tier of neck cells. $X$ approx. 180. 42. Surface view of archegonial neck (Nomarski optics), showing enlarged cells of uppermost neck tier. $\times$ approx. 200. 

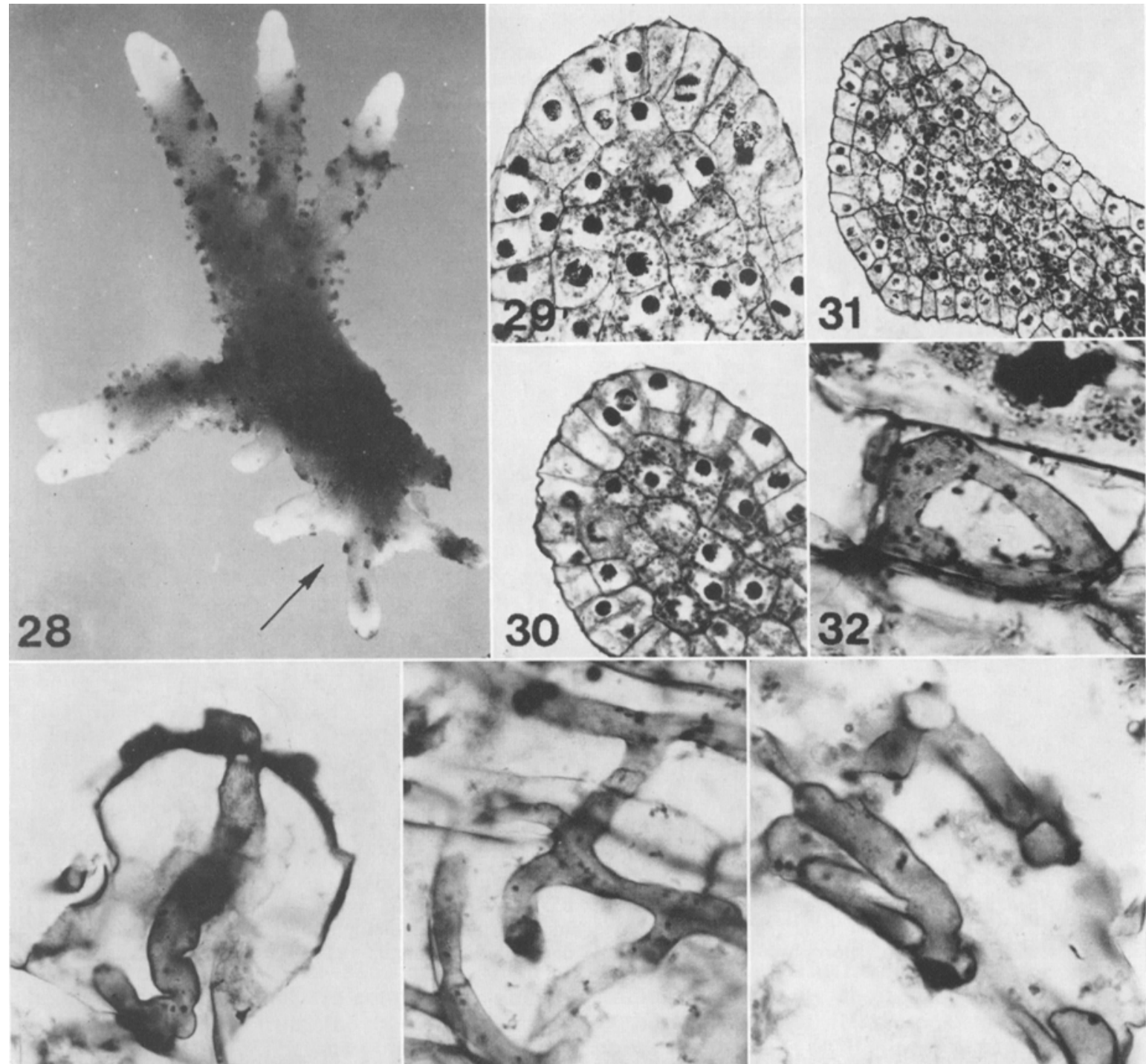

\section{ㄴ.}

$$
\text { 캇 }
$$
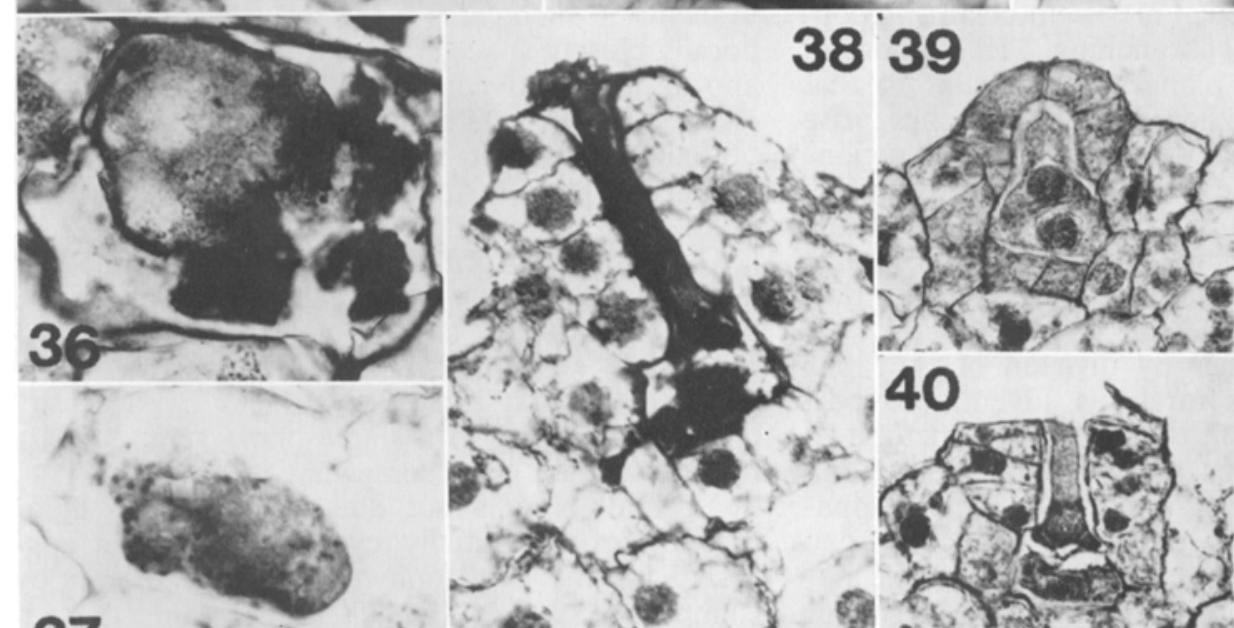

37

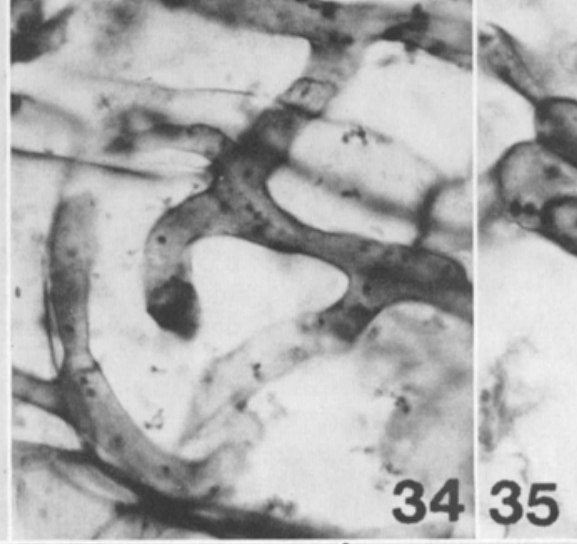

\section{9}




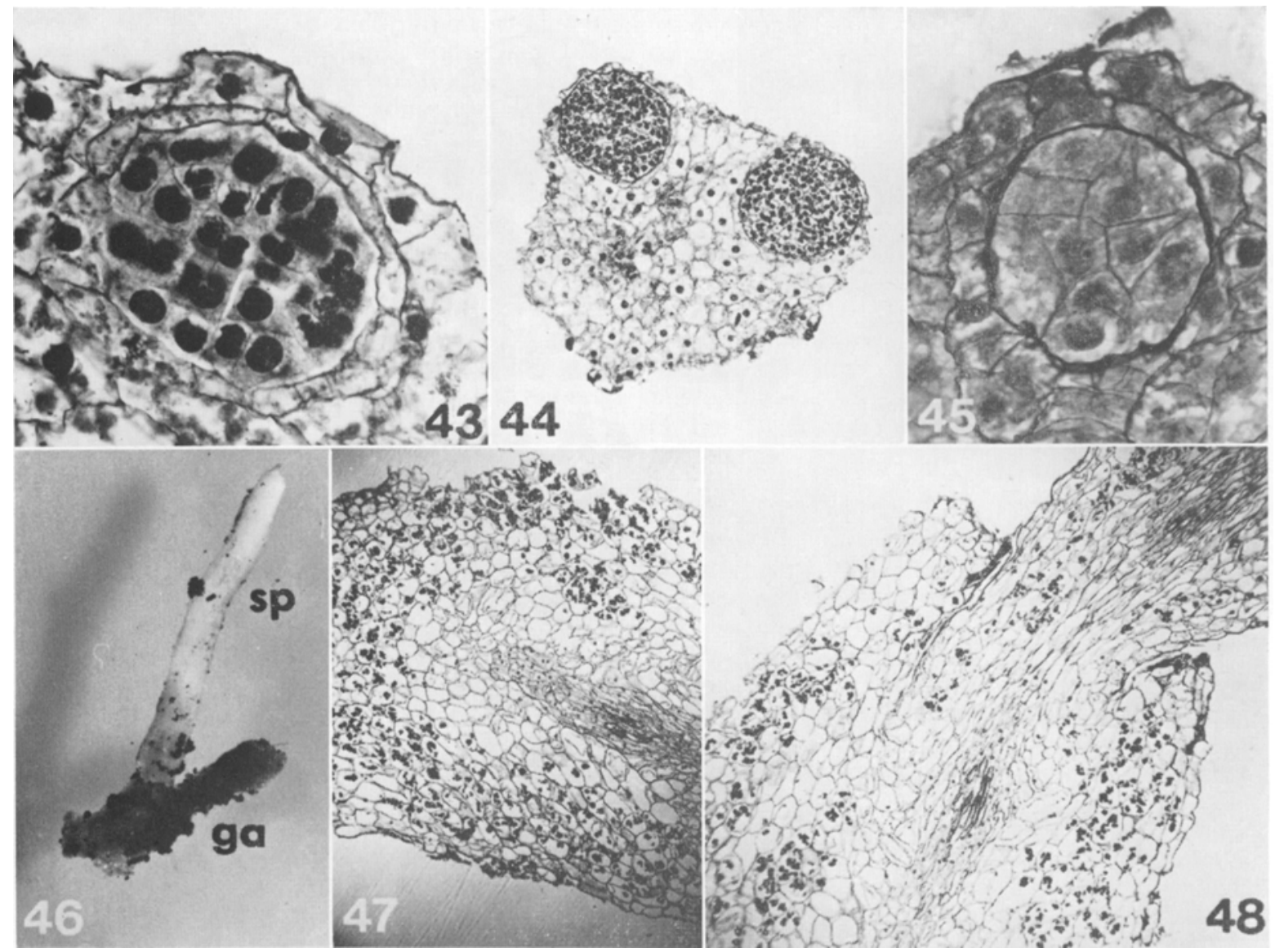

Fig. 43-48. Ophioglossum palmatum. 43. Section of developing antheridium. $\times 235$. 44. Cross section of gametophyte axis, showing relative size of antheridia. $\times 65.45$. Section of young, spherical embryo (approx. 16cell stage). $\times 240$ 46. First root $(\mathrm{sp})$ of sporophyte emerging from gametophyte (ga). $\times 7.5$. 47, 48. Longitudinal sections of base of sporophyte in Fig. 46. Note dark staining fungus vesicles in gametophyte tissue. 47, $\times 32 ; 48, \times 32$.

cross-sectional shape is the result of periclinal divisions near the apex and is associated with the enlargement of the apical meristem occurring concomitant with apical branching. Expansion of the axis occurs in a plane perpendicular to that of the branching. When several branches arise simultaneously or in close succession, the regions of apical meristematic activity become extensive. Depending on the number and orientation of the branches, the gametophyte body may be almost radially symmetrical or show pronounced flattening.

Branches arise either by division of the apex (Fig. 21) or perhaps rarely as adventitious outgrowths from older portions of the gametophyte body. Apical divisions may be equal (Fig. 24) or unequal (Fig. 5) and may result in the formation of two or more branches. Branching can occur successively or simultaneously. In the latter case, an enlarged apex is composed of two or more incipient branches of approximately equal size. No evidence is available, however, to exclude the possibility that formation of multiple branches in such cases is the result of several temporally closely spaced, successive divisions. What appear to be adventitious branches arising from differentiated gametophyte tissues in most cases probably represent the latent growth of meristematic centers formed by an extremely unequal division of the gametophyte apex (Fig. 26, 28).

Gametophyte form is probably determined to a large extent by the microhabitat features of the palmetto leaf-base substrate. For example, gametophytes which develop in the narrow space between two flat leaf-base surfaces by necessity confine branching to a single plane (e.g., stellate forms) and are often somewhat flattened (Fig. 4, 26). Flattening is not due to the actual compression of an initially cylindrical axis as suggested for the gametophytes of $O$. pendulum by Campbell (1907). Instead, it represents the accommodation of gametophyte development to the 
space available. Gametophytes living in a less restricted space, on the other hand, are more threedimensionally branched and less flattened. Branching is not regular, however, and reflects repeated adjustments to various obstacles such as the fibrovascular bundles of the palmetto.

Proliferation by fragmentation is common, resulting from the indeterminate growth of the gametophyte axis, repeated apical branching, and decay of older parts of the gametophyte (Fig. 14). Small groups of apices are derived from individual branched gametophytes whose proximal regions have decayed; under favorable conditions each of the apices gives rise to a mature gametophyte which, in turn, may fragment in a similar manner. Renewal of apical growth, as observed for specimens kept in jars in the laboratory, is often marked by the enlargement of the apex and its concomitant subdivision into two or more growth centers. This process of fragmentation can account for the large groups of 100 or more apices which have been observed and can be expected to result in the formation of relatively extensive gametophyte clones.

All gametophytes bear both antheridia and archegonia. The distribution of each is variable, however, and no pattern could be established. Development of gametangia is strictly acropetal. Although antheridia are frequently present at the bases of the available specimens, suggesting protandry, the indeterminate growth and decay of older parts of the axes confounds interpretations of the relative order of gametangial maturation.

Gametangial development is almost identical to that described for Ophioglossum pendulum by Campbell (1907, Fig. 62-74, 98-118). Mature antheridia are large $(175-325 \mu \mathrm{m}$ in diam), spherical to ellipsoid, and are completely sunken or more often bulge from the body of the gametophyte (Fig. 44). They may produce an estimated 2500 or more sperm cells, which are discharged through a single operculum (Fig. 27). The outer wall of the antheridium consists of two cell layers. The inner wall layer consists of flat cells and completely surrounds the antheridium (Fig. 43). The cells of the outer layer, on the other hand, are not readily distinguishable from the adjacent surface layer cells of the gametophyte. The neck of the mature archegonium consists of 4-5 tiers of cells, 2-3 of which usually extend above the surface of the gametophyte (Fig. 38-40). The cells of the uppermost tier are conspicuously swollen and fold back at the time of dehiscence in a manner similar to that described for Botrychium virginianum by Bierhorst (1958; Fig. 41, 42).

Embryos-A limited number of gametophytes with embryos were found, not enough to establish a complete developmental series. All gametophytes with embryos have active apical meristems; evidently, the beginning of sporophyte growth does not terminate gametophyte growth. In several Ophioglossum species a gametophyte produces a single sporophyte. However, in O. palmatum a gametophyte can give rise to several embryos (Fig. 23, 25).

The youngest embryo observed consists of a spherical group of ca. 16 undifferentiated cells (Fig. 45). Older embryos (Fig. 25), consisting of 100-200 cells, are spherical to elongate and 0.4-0.9 mm long. In these, meristematic activity is restricted to the upper hemisphere where, in all specimens, I observed the initial stages of organization of a radially symmetrical meristem similar to a root apical meristem. The meristem is located within the tissue of the embryo, 2-5 cell layers beneath the surface. No other meristematic centers or incipient organs could be recognized. The lower part of the embryo, in contact with tissue of the gametophyte, consists of larger, less densely cytoplasmic cells. In contrast to the adjacent cells of the gametophyte, those of the embryo have numerous starch grains.

The oldest embryo is shown in Fig. 46. It consists of a single, unbranched root, $6 \mathrm{~mm}$ long, arising from a gametophyte. There is no evidence of the presence of leaf primordia or a stem apical meristem. The base of the young sporophyte axis is slightly expanded within the gametophyte, forming a foot-like structure (Fig. 47, 48). The outer cells of this region are in close contact with the gametophyte and the boundary between sporophyte and gametophyte is difficult to detect. The possibility of apogamy cannot be ruled out. A single vascular strand runs without interruption from the base of the foot to the base of the root apical meristem. The tracheids at the base of the strand are relatively short and broad compared to those of the root. Numerous starch grains are present in the cells of the upper $1 \mathrm{~mm}$ of the root, and fungal hyphae, similar to those of the gametophyte, occur in the cortex of the lower half of the root and the uppermost tissues of the foot.

Discussion-The data presented in this paper allow the following conclusions: (1) The gametophytes of Ophioglossum palmatum are more similar to those of $O$. pendulum than to other described Ophioglossum gametophytes. (2) Whereas the gametophytes of $O$. palmatum (and $O$. pendulum) are unusual when compared to other Ophioglossum gametophytes, they are fundamentally similar in structure and development. (3) Gametophyte characters, therefore, provide no compelling evidence for placing $O$. palmatum in its own genus, viz., Cheiroglossa Presl.

Most known Ophioglossum gametophytes are cylindrical with an enlarged basal end, are simple or branched only a few times, and bear slender, thread-like rhizoids. In contrast, the gametophytes of $O$. pendulum, described by Lang (1902) 
and Campbell $(1907,1911)$, are much branched, bear papillose rhizoids, and may be irregular in form, ranging from cylindrical to stellate. In addition, whereas growth of the gametophytes of most species is determinate, stopping with the development of a single young sporophyte, the growth of the gametophytes of $O$. pendulum is potentially indeterminate, and each gametophyte may give rise to several embryos. Repeated apical branching and decay of older parts of the axis result in propagation of gametophytes by fragmentation.

The gametophytes of Ophioglossum palmatum, described for the first time in this paper, resemble those of $O$. pendulum in the following characters: (a) habit and branching pattern, (b) size, (c) indeterminate growth and proliferation by apical fragmentation, (d) production of more than a single embryo per gametophyte, (e) short, wide rhizoids, and (f) size of antheridia.

Gametophytes of Ophioglossum palmatum, although superficially different from most others in the genus, have the same basic features shared by all Ophioglossum gametophytes: (a) they are cylindrical, (b) grow by means of a radially symmetrical apical meristem, and (c) bear antheridia, archegonia, and rhizoids interspersed along the axis. The main modifications of this basic organization shown by $O$. palmatum are (a) increase in the frequency of branching, (b) expansion of the gametophyte axis in some cases, and (c) the concomitant change from the basic cylindrical form. The latter modification is not constant, however, and a complete series of mature gametophytes links the cylindrical forms to thickened and often flattened axes. Although Foster (1964) suggested that the expanded, noncylindrical gametophytes of $O$. pendulum figured by Lang (1902) and Campbell (1907) resulted from the activity of a lateral meristem producing secondary growth, neither Campbell nor Lang mention such a meristem, and I have been unable to identify one in similar gametophytes of $O$. palmatum. Foster also interprets the conspicuous radial seriation of the outer cell layers of $O$. vulgatum gametophytes figured by Bruchmann (1904) as indicating the activity of a thickening meristem, and Bierhorst (1971) reports, without documentation, a peripheral thickening meristem operating at the older ends of $O$. vulgatum gametophytes. Expansion of the gametophyte axis of $O$. palmatum (and most likely also $O$. pendulum) results from extensive periclinal divisions in the superficial cell layer of the apical meristem and parts of the axis immediately behind the apical meristem. It seems probable that the radial seriation observed for $O$. vulgatum similarly results from periclinal divisions, of a more restricted extent, occurring at the apex.

Based on an analysis of an incomplete series of
O. pendulum embryos, Campbell (1907) came to the conclusion (a) that the embryo gives rise only to a foot and roots and (b) that the shoot arises as a bud on one of the primary roots. This unusual interpretation was disputed by Wardlaw (1955) and has been ignored in modern, comprehensive texts (see, for example, Eames, 1936; Bierhorst, 1971). My observations of the embryogeny of $O$. palmatum, however, suggest that Campbell's interpretation may apply for this species.

The oldest embryo I found still attached to a gametophyte (Fig. 46) consists of a single root with an expanded, foot-like region at the base. There is no indication of other incipient organs at the base of the root. Although I did not observe roots bearing shoot buds still attached to their parent gametophytes, numerous detached, slender roots, which did not appear to have arisen from stems, were discovered, and many of these bore small buds at their tips. In addition, all young leaf-bearing plants I discovered showed clear indications of origin as root buds.

Bruchmann (1904) observed that all primary organs of $O$. vulgatum arise from the original embryo but that the first root is precocious and may precede other organs by several years. It might be argued, therefore, that the specimen illustrated in Fig. 46 represents an early stage in an embryogeny of essentially the $O$. vulgatum type and that the shoot and first leaf would have eventually formed at the base of the first root. On the basis of existing evidence, I believe that this alternative interpretation cannot be totally discounted. However, what might be considered deciding evidence for the hypothesis I have advanced, i.e., discovery of shoot buds on root attached to parent gametophytes, may not be forthcoming due to decay of gametophytes and proximal parts of embryos prior to development of the shoot bud.

Most authors have regarded Ophioglossum palmatum and $O$. pendulum as only distantly related. This is reflected in the generic and subgeneric taxonomic systems they have adopted (e.g., Copeland, 1947; Prantl, 1884; Nishida, 1952) or in the phylogenetic schemes they have devised (e.g., Mahabale, 1962; Maroti, 1965). In contrast, Nakai $(1925,1926)$ placed both species together in a separate genus Ophioderma (Blume) Endlicher. The main differences between the sporophytes of the two species have been enumerated by Clausen (1938), Taton (1944), and Mesler (1974).

Evidence from the gametophyte generation supports the hypothesis that $O$. palmatum and $O$. pendulum are closely related. The gametophytes of the two species share many unusual features and are more similar to one another than to other Ophioglossum gametophytes. The same may be true of the embryos and young sporophytes of 
the two species. In addition, new information on the structure of the stomates supports this hypothesis. Maroti (1965) reported that both species are unique in the genus in having cyclocytic arrangement of subsidiary cells; nevertheless, he regarded this as a case of parallel evolution. Van Cotthem (1970), however, divided the genus Ophioglossum s. $l$. into two subgroups on the basis of stomate characters, including $O$. pendulum, $O$. palmatum, and $O$. bergianum in one group. Thus, information from the gametophytes, embryos, and stomates suggests the need for a reevaluation of the relationships of $O$. pendulum and $O$. palmatum.

Several authors (Presl, 1845; Endlicher, 1836; Nakai, 1925; Christensen, 1932; Small, 1938; Copeland, 1947; Tardieu-Blot, 1953; Nishida, 1952; Pichi-Sermolli, 1954; Maroti, 1965) have treated Ophioglossum $s$. $l$. as comprising two or more separate genera, viz., Ophioglossum L., Rhizoglossum Presl, Cheiroglossa Presl, and Ophioderma (Blume) Endlicher. These treatments have been based on such sporophyte characters as shape of the sterile leaf segment, point of insertion of the fertile spike, number of fertile spikes, and number of leaf traces. A survey of the diversity of sporophytes in the genus does, in fact, support the recognition of species clusters although the exact boundaries and relationships of such have not been defined. Likewise, gametophytes are not monotonously uniform in the genus, as pointed out in this paper, and gametophyte characters also suggest possible subgroups.

If one agrees that, for example, Ophioglossum palmatum is sufficiently different from other members of the genus to warrant separate taxonomic recognition, then, of course, the rank to be applied must be given careful consideration. In general, biologists have considered the limits of taxonomic categories above the level of species to be arbitrary and based primarily on the judgement of the individual taxonomist (Mayr, 1963). However, most agree that a good generic system should reflect both real biological discontinuities as well as provide a workable tool for nonspecialists. Generic differences in a family should be, as far as possible, of approximately equal magnitude. It seems clear that whereas, for example, $O$. palmatum differs in many characters, both sporophytic and gametophytic, from other members of the genus, the differences are not as great as those among the traditionally defined genera in the family, Botrychium, Helminthostachys, and Ophioglossum. I believe that the interests of a useful, consistent taxonomy can best be served by including all species in the easily recognized genus Ophioglossum and that evolutionary relationships within the genus can be represented accurately by using subgeneric categories. In view of this, placement of $O$. palmatum in a sub- genus (viz., Cheiroglossa or Ophioderma, depending on consideration of the relationships of $O$. pendulum and $O$. palmatum) seems justified.

\section{LITERATURE CITED}

BIERHORST, D. W. 1958. Observations on the gametophytes of Botrychium virginianum and $B$. dissectum. Amer. J. Bot. 45: 1-9.

1971. The morphology of vascular plants. Macmillan, New York.

BoullaRD, B. 1963. Le gametophyte des Ophioglossacèes. Considerations biologiques. Bull. Soc. Linn. Normandie 4: 81-97.

BruchmanN, H. 1904. Ueber das Prothallium und die Keimpflanze von Ophioglossum vulgatum $\mathbf{L}$. Bot. Z. 62: 227-247.

BurgefF, H. 1938. Mycorhiza, p. 159-191. In F. Verdoorn [ed.], Manual of pteriodology. Martinus Nijhoff, The Hague.

CamprelL, D. H. 1907. Studies on the Ophioglossaceae. Ann. Jard. Bot. Buitenzorg 6: 138-194. . 1911. The Eusporangiatae. Publ. Carnegie Inst. Washington No. 140.

Christensen, C. 1932. The pteridophyta of Madagascar. Dansk Bot. Ark. 7: 1-253.

Clausen, R. T. 1938. A monograph of the Ophioglossaceae. Mem. Torrey Bot. Club 19(2): 1-177.

Copeland, E. B. 1947. Genera filicum. Chronica Botanica, Waltham, Massachusetts.

EAMES, A. J. 1936. Morphology of vascular plants. Lower groups. McGraw-Hill, New York.

ENDLICHER, S. L. 1836. Genera plantarum, Vienna.

FosteR, D. B. 1964. The gametophytes and embryogeny of five species of Botrychium. Ph.D. thesis, Cornell University, Ithaca, New York.

HERR, J. M. 1971. A new clearing-squash technique for the study of ovule development in angiosperms. Amer. J. Bot. 58: 785-790.

LaNG, W. H. 1902. On the prothalli of Ophioglossum pendulum and Helminthostachys zeylandica. Ann. Bot. 16: 23-56.

Mahabale, T. S. 1937a. The gametophyte of Ophioglossum aitchisoni d'Alm. (Abstr.) Proc. 24th Ind. Sci. Congr., Hyderabad, 1937, p. 265.

1937b. Ibid. p. 265.

1937c. Ibid. p. 265-266.

1962. Species of Ophioglossum in India: their taxonomy and phylogeny. Bull. Bot. Surv. India 4: 71-84.

MarotI, I. 1965. Vergleichende anatomische Untersuchungen an den Blättern der Ophioglossaceae. Acta Biologica (Szeged) 11: 55-71.

MAYr, E. 1963. Animal species and evolution. Belknap Press, Harvard University, Cambridge.

MesLeR, M. R. 1972. The gametophyte of Ophioglossum palmatum L. (Abstr.) Amer. J. Bot. 59: 679 - 1973. Sexual reproduction in Ophioglossum crotalophoroides. Amer. Fern J. 63: 28-33.

- 1974. The natural history of Ophioglossum palmatum in South Florida. Amer. Fern J. 64: 33-40.

NaKaI, T. 1925. Notes on Japanese ferns. Bot. Mag. Tokyo 39: 192-194.

. 1926. Notes on Japanese ferns. Bot. Mag. Tokyo 40: 371-396. 
NishidA, M. 1952. Studies on the systematic position and constitution of pteridophyta. 4. Rhizoglossum in Japan and its systematic position. J. Coll. Arts Sci. Chiba Univ. 1: 80-85.

Pichi-Sermolli, R. E. G. 1954. Adumbratio Florae Aethiopicae. 3. Ophioglossaceae, Osmundaceae, Schizaeaceae. Webbia 9: 623-660.

Prantl, K. 1884. Beiträge zur Systematik der Ophioglosseen. Jahrb. Bot. Gart. Berlin 3: 297-350.

Presl, K. B. 1845. Supplementum Tentamis Pteridophyta. Abh. Bohm. Ges. Wiss. 4: 301-320.

Sharman, B. C. 1943. Tannic acid and iron alum with safranin Orange $G$ in studies of the shoot apex. Stain Technol. 18: 105-111.
Small, J. K. 1938. Ferns of the southeastern States. Science Press, Lancaster, Pa.

Tardieu-Blot, M. L. 1953. Les pteridophytes de l'Afrique intertropicale Française. Memories de l'Institut d'Afrique Noire 28: 1-241.

Taton, A. 1944. Ophioglossum louisii Taton sp. nov. Épiphyte remarquable de la forêt équatoriale Congolaise. Bull. Jard. Bot. Etat Bruxelles 17: 117127.

Van CotThem, W. 1970. Comparative morphological study of the stomata in the Filicopsida. Bull. Jard. Bot. Nat. Belg. 40: 81-239.

WARDLAW, C. W. 1955. Embryogenesis in plants. Methuen, London. 